\title{
CHARACTER STRENGTH AND VIRTUES IN THE PERSPECTIVE OF ISLAMIC EDUCATION PSYCHOLOGY
}

\author{
Alivermana Wiguna, Jayadi, Agus Heriyanto, Fatimah Setiani, Gita Anggraini, \\ Harun Joko Prayitno, Gamal Abdul Nashir Zakaria \\ *Correspondent Author
}

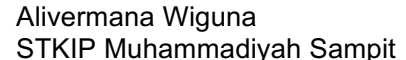

Jl. Kihajar Dewantara No. 3 Sampit,

Kalteng

Indonesia

Email:

alivermana_wiguna@stkipmsampit.ac.id

Jayadi

STKIP Muhammadiyah Sampit

Jl. Kihajar Dewantara No. 3 Sampit, Kalteng

Indonesia

Email: Jayadi@stkipmsampit.ac.id

Agus Heriyanto

STKIP Muhammadiyah Sampit

JI. Kihajar Dewantara No. 3 Sampit,

Kalteng

Indonesia

Email:

agus_heriyanto@stkipmsampit.ac.id

Fatimah Setiani

STKIP Muhammadiyah Sampit

Jl. Kihajar Dewantara No. 3 Sampit, Kalteng

Indonesia

Email:

fatimah_setiani@stkipmsampit.ac.id

Gita Anggraini

STKIP Muhammadiyah Sampit

Jl. Kihajar Dewantara No. 3 Sampit,

Kalteng

Indonesia

Email:

gita_anggraini@stkipmsampit.ac.id

Harun Joko Praytno

FKIP Universitas Muhammadiyah

Surakarta

harun.prayitno@ums.ac.id

Gamal Abdul Nasir Zakaria

Sultan Hasanah Bolkiah Institut of

Education, University of Brunei

Darussalam, Brunei

gamal.zakaria@ubd.edu

Page

14-25

\section{ABSTRACT}

The present study aimed to identify and formulate Ibnu Miskawaih's and Imam Al-Ghazali's idea of character strength and virtue. To this end, a qualitative literature review was applied. The literature included books and journals related to character strength and virtue formulated by positive psychology The data were analyzed in descriptive-reflective-instrospective ways within Islamic psychology perspective. It was found that in terms of number and composition of character strengths and values of virtues, there was a significant difference between positive psychology and Islamic education psychology. There was a slight difference between character strength in positive psychology and that in Islamic education psychology in the form of the presence of middle way. This middle way, as sharia' stipulates, aims to provide a balance in all nature and quality of virtue. The finding of the study contribute to the field of guidance and counseling by proposing the reinforcement of character strength and virtue in this globalization era.

Keywords: character strength, virtue, ibnu miskawaih, imam alghazali, islamic education psychology, guidance and counseling 


\section{INTRODUCTION}

In 2000s, the object of Western psychological studies had begun to change their direction, especially after a new school of psychology, known as positive psychology, was established. Positive psychology believes that character strength and virtues should be optimized in every individual. This character strength consists of six aspects, namely wisdom and knowledge, courage, humanity and love, justice, temperance, and transcendence. Each aspect of character strength contains two to six virtues, and twentyfour virtues in total. Character is the core strength in the field of educational psychology (Biyanto, 2017; Daniati, Subiyantoro, \& Sutarmi Fadhilah, 2019; Prayitno et al., 2019).

The proposition of character and virtue designed by American psychologist, Martin E.P Selignman Seligman, and other advocates of positive psychology stems for religious tenets and life philosophy around the world, including Islamic tenet and Al-Quran (Seligman, Authentic Happines: Menciptakan Kebahagiaan dengan Psikologi Positif, 2005). Almost all of them converge on the six strengths of character above, although the naming and numbers can vary slightly. Character reflects diversities (Okech, 2016; Prayitno, H.J., 2019; Susilo \& Dalimunthe, 2019).

For Islamic community, let alone the scholar of Islamic education psychology, it is interesting that character strength and virtue has been formulted in Islam long time ago. In Al-quran, there are many formulation and concept of character and virtue, some of which could be found in prophets' and pious people's told in AlQuran Character strength and virtue are also discussed in hadith, proving that Virtue and character of Islam community does not emerge immediately, it is supported by pre-Islamic Arabic culture. According to Toshihiku Izutsu, the virtue of pre-Islamic Arab community greatly contribute the character strength and virtue in Islam(Izutsu, 1993), , which was practiced by Prophet Muhammad and the formulated by Islamic scholars in the next period (Hitti, 2008)

Abu Ali Ahmad bin Muhammad bin Ya'kub Ibnu Miskawaih (941-1030M), known as Ibnu Miskawaih, and Abu Hamid Muhammad AlGhazali (1058-1111M), or Imam Al-Ghazali, are two among other Islamic scholars who concerned with character and virtue (Haque, 2004). Accordingly, it is important to explore their thouths in order to understand the insight that can be developed and applied in this modern era. So that as scholars in the Islamic education psychology, we are able to interact with it in the arena of today's modern science, without losing the root of the study on character strength. The main research question of this study is : According to Ibnu Miskawaih and Imam Al-Ghazali, How are character strength and virtue formulated?

A person's character is a very important driving force in strengthening character education (Prayitno, 2019; Qurrota A'yun, M 2017). Therefore, studying these two figures is very interesting and comprehensive (Prasetiya, 2018), moreover, the character strength and virtue which they formulate are the midpoint between the two ends, and in this case the two ends constitute vices, one advantage perhaps over those formulated by Western psychologists. For example, in Ibn Miskawaih's formula, one of the virtues of the strength of the character of wisdom is being clever (adzdzaka). Cleverness is the midpoint between two points, stupidity (al-baladah) and mental rottenness (khabatsu), such as cunning, trickery, and acts of manipulation..

The study was conducted to identify and formulate the character strength and virtue according to Ibn Miskawaih and Imam AlGhazali. The formulation of character strength based on these Islamic figures is expected to be able to form a virtue character that can be inherent in individuals. Hopefully, these findings can provide a valuable contribution in counseling guidance services through strengthening character and virtue in the current era of global communication.

\section{METHODOLOGY}

The present study applied qualitative literature review. This was done by reviewing relevant works such as book and journals related to the character strength and virtue defined by Ibnu Miskawaih and Imam AlGhazali. The data were analyzed descriptively, reflectively, and introspectively from Islamic psychology perspective, covering background of problem, character strength and virtue in positive psychology, and character strength and virtue in Islamic education psychology perspective.

\section{RESULT AND DISCUSSION}

Positive psychology is defined as a study on a condition and process that cause individuals, groups, or institutions to optimally develop and function (Linley, Joseph, Harrington, \& Wood, 2007). Such a development refers to development of positive innate potential of every individual. 


\section{6| PSIKOPEDAGOGIA}

JURNAL BIMBINGAN DAN KONSELING

Vol.9, No.1, June 2020

Declared by Martin E.P. Sellignman in 1997 during his speech as the president of American Psychological Association, Positive psychology is the most recent study in the field of psychology. In his speech, Selignman states that before the second world war, psychology holds three missions, namely: to cure mental illness, to make life happier, and to identify high talent. However, it its practice, the last two missions were abandoned.

Based on this fact, Selignman, in his declaration, focused psychology on the two last missions by enforcing three pillars of positive psychology (i.e., study on positive emotion, study on positive trait, especially character strength and virtue, and study on positive institutions that support virtues).

Positive psychology is a breakthrough when the existing psychology movement,at that time, focused more on human abnormalities and disorders. According to Jalaluddin Rahmat, psikologi positif telah meninggalkan psikologi "bengkel" yang memperbaiki jiwa-jiwa yang rusak, menuju psikologi "pandai emas" yang menyepuh jiwa yang mulia menjadi lebih cemerlang (Rahmat, 2005). It is in line with Noeng Muhadjir who states that the old pathogenic-oriented psychology, which focuses on examining clients' disorder and misbehavior, has shifted into salutogenic psychology that reinforces and develop individuals' psychological strength (Muhadjir, 2011).

By the presence of positive psychology, psychological studies are expected to pay closer look to the development of positive values of individuals. This positive psychology brings new hope, guides people to achieve their life goals and meaning, and to achieve happiness. Character strength is a positive trait or character that is reflected in thoughts, feelings, and behaviors (Park, Peterson, \& Al, 2004). The strength of this character is a small part of the personality traits that are placed on the value of moral (Park et al., 2004) or virtue..

Character is similar with the term Akhlaq in Islamic studies. Akhlak or "khuluq" is the stability of the soul that produces actions or practices easily, without having to think about or consider it in a deep sense (Miskawaih, 1994) (Mar'ati, 2014). The stability of the soul here means the stability of being able to behave and do good, which is based on Islamic norms and teachings, moral awareness and the purity of the soul. (Wahidah, 2016). Therefore, it is necessary to train one's akhlak to develop (Setiawan, 2014). Positive psychology, a branch of Western psychology that studies virtues and strength, provides individuals with opportunities to grow healthily, sees that humans are dominated by their positive potential, namely positive emotions, positive traits, and positive institutions. (Seligman, Foreword, 2004).

There are three kinds of happiness to be achieved in positive psychology: (1) meaningfulness in all actions; (2) knowing the greatest strength; and (3) use it to serve something that is believed to be something greater than oneself. Obviously, these three forms of happiness are closely related to human virtue and strength. In positive psychology, virtue, according to Martin Seligman, is divided into six categories: 1) wisdom and knowledge); 2) courage; 3) humanity and love; 4) justice; 5) (temperance); and 6) transcendence (Seligman, Classification and Measurement of Character Strength, 2004).

Wisdom and knowledge is a virtue related to cognitive function, which is about how to get and use knowledge. This virtue consists of six characters, namely: (1) curiosity or interest in the world; (2) loves learning; (3) critical thinking and openness; (4) originality and practical intelligence; (5) social intelligence or emotional intelligence; and (6) perspective or the ability to understand a variety of different perspectives and synergize them for the achievement of a good life. Courage is an emotional virtue that involves a strong willingness to achieve a goal despite obstacles or opposition, both external and internal. This virtue includes three characters, namely: (1) courage; (2) fortitude or persistence; and (3) integrity, honesty and present themselves as they are. Humanity and love are virtues that includes interpersonal skills and how to make friends with other people. The strengths involved in this virtue are: (1) kindness and generosity; always have the time and energy to help others; and (2) loving and allowing oneself to be loved.

Justice underlies a healthy life in a society. There are three strengths involved here: (1) citizenship or capable of carrying out duties, dedicated and loyal for mutual success; (2) fairness and equality; treat others equally or do not discriminate against the treatment given to each person; and (3) leadership. Self-control is the virtue of protecting oneself from all the bad consequences that may occur in the future due to one's own actions. It includes the strengths of character: (1) self-control or the ability to hold back; (2) caution; and (3) humility. Transcendence, is the virtue that connects human life with the entire universe and gives meaning to life. Within this virtue there are six 
characteristics: (1) respect for beauty and perfection; (2) gratitude for all good things; hopeful, optimistic and future-oriented; (3) spirituality; has a purpose that leads to union with the universe; (4) forgiving and forgiving; (5) enjoy life and have an adequate sense of humor; and (6) have great enthusiasm and passion to meet each day.

Toshihiku Izutsu in his book EtichoReligious Concepts in The Qur'an, explains that the contribution of old pre-Islamic Arabic virtues is quite thick in Islamic teachings. This virtue is not entirely good because it grows and develops in Arab society which is pagan, idolatrous, warlike, proud, extravagant, respectful and various other idolatrous traits. However, after being purified by the teachings of monotheism and refreshed with noble morals, it becomes a very valuable virtue in Islam. (Haque, 2004). Accordingly, Ali bin Abi Talib once described the personality figure of the Prophet Muhammad SAW as a typical hero of the desert Arab community as revealed by Ibn Hisyam in Sirat an-Nabinya: "He is a very generous person, very brave, very honest in his speech, very loyal in upholding the truth, very calm in thinking and very warm-hearted in socializing. Those who see him for the first time will be afraid, but those who already know who he really is will love him" (Izutsu, 1993).

Likewise with Michael Hart, one of the reasons why he put Prophet Muhammad the most influential figures in history is that he, Prophet Muhammad, was a simple man, at the same time he was also a strong, genuine, and effective leader. Fourteen centuries have passed, but his influence is still strong and deep and rooted (Hart, 1989). So what are the virtues of the pre-Islamic Arab society? First, generosity. For pre-Islamic Arabs who lived in a vast and barren desert, hospitality, help, and charity were very important aspects in maintaining their life and muruwah (selfrespect). But unfortunately the purpose of these three acts of virtue is none other than self-pride, to gain respect as the most noble, and to be considered a knight. So that people who do the most good deeds are seen as the most dignified in the desert. Pre-Islamic poets used to boast of drinking their wine as a sign of generosity and true glory. Drinking this wine is usually followed by drunkenness and squandering of wealth, giving without limits, so as to cause the highest amazement in the minds of the visitors..

When Islam came, the boundless generosity of the pre-Islamic Arab society was included into the values of monotheism by Islam. So that their ingrained hospitality, helpfulness, and charity do because they are arrogant and arrogance becomes full of meaning and value, as mentioned in QS. Al-Baqarah [2]: 264-266; Al-Isra [17]: 26-27, 29-30; Al-Furqan [25]: 67. Second, courage; it is common in the desert that courage or masculinity is placed in a very high position, above other values, and is a very essential element of their muruwah. For desert Arabs, bloody fights with personal or tribal motives became a passion for life. So that at the next level, this courage builds self-confidence and aggressiveness. A soldier, fierce as a lion, strikes back and punishes his enemy if the enemy ever attacks him, one must take the initiative and become the attacker if no one cheats him. As a result, the values of courage and bravery in the pagan Arabs were no better than the cruelty and inhuman ruthlessness that ensued in inter-tribal hostilities. So that courage is for courage itself.

When Islam came, Islam also paid the highest respect to those people who were never afraid of danger, who bravely and courageously faced the enemies of the polytheists and the kafirins in every battle, and denounced cowards who were reluctant to be present on the battlefields. But in Islam, courage and courage are no longer blind impulses and difficult to control. Courage becomes something noble, because it is based on high discipline with a lofty goal based on true religion, namely courage in the path of Allah. (jihad fi sabilillah), QS. At-Tawbah [9]: 123; At-tawbah [9]: 13-15. Third, loyalty. Faith and trust is a feature of the highest and most obvious values in the desert, which every reader of pre-Islamic poetry and tradition admits. As is well known, the loyalty value of ignorant people is generally related to kinship because of blood relations. This generally applies within tribal boundaries; it is in this narrow environment that loyalty has absolute and supreme control. This loyalty manifests in the most impartial self-purification for the sake of kinship, the highest loyalty to friends, and also the utmost obedience in keeping the covenant firmly. In fact, often these treaties can extend to the effectiveness of their values even beyond tribal boundaries. This is illustrated from the typical example of Samaw'ad bin 'Adiya, he was urged by a despot to open the envelope of the letter which the poet Imru al-Qays entrusted to him. Samaw'ad refused to obey the tyrant, as a result he had to witness his son being slaughtered in front of him. The name Samaw'ad has been the byword of the Arabs as the embodiment of the highest ideal of Bedouin loyalty. 


\section{8| PSIKOPEDAGOGIA}

JURNAL BIMBINGAN DAN KONSELING

Vol.9, No.1, June 2020

Fourth, honesty. Honesty is seen as the most superior value in the Arab community of the desert of Jahiliyah. Honesty is evenly distributed throughout society, is a common practice and an ingrained feature of human values. In the view of the Koran, this is accepted as an extraordinary characteristic, which will be clearly seen when we approach it from the negative side, namely sin due to lies. Fifth, patience; patience, fortitude or endurance, was a prominent value in the desert environment of the Jahiliyah era. In the desert, with such a harsh way of life, every human being is constantly forced to show extraordinary patience and endurance for his personal life as well as for the survival of his tribe. Physical strength is of course necessary, but it is not sufficient. Resilience must be supported by something from within, namely patience, word of mouth, and courage in order to be ready to face all challenges.

The cultural value of this old nomad tribe was also transformed by Islam into one of its main values, by complementing it with a definite religious requirement: patience in the way of Allah. As in the era of ignorance, in particular, patience in Islam is commanded to every believer who is fighting on the battlefield against the infidels. (Surah Al-Baqarah [2]: 249-251, Ali Imran [3]: 146). Patience is a distinctive aspect of belief that is shown when a person is in unfavorable conditions, as experienced by Muslims in the early days of the Mecca period.

His full name is Abu Ali Ahmad bin Muhammad bin Maskawaih or Miskawaih, born in Ray in $330 \mathrm{H} / 941 \mathrm{M}$. Some people say that he used to be a Magi, but others say that his father was originally a Magi and then converted to Islam (Syarif, 1996). Ibn Miskawaih had good relations with important people and rulers of his time. He once served Abu Fadl Al-Amid as his librarian, with the nickname Al-Khazin. After the death of Abu Fadl, Ibn Miskawaih served his son Abu Al-Fath Ali bin Muhammad Al-Amid (Azra, 2005). Ibn Miskawaih was basically a historian and moralist as well as a poet. Although At-Tauhidi criticized him that he was a miser and a hypocrite, his interest in learning AlKimia was not because of knowledge but because of gold and wealth. But in the following years he has tried to follow the fifteen points of moral instruction. Even lqbal considered him to be the most famous Persian theistic thinker, moralist, and historian (Syarif, 1996). He talks about moral changes in his book Tahzib AlAkhlak, which shows that he is doing well what he has written. (Taufiqharahap, 2017). His simplicity in overcoming lust, persistence in submitting self-greed and policies in regulating irrational impulses are the main points of his teachings. Abu Hayyan describes the personality of Ibn Miskawaih as a person whose speech is very soft, easy to digest, contains very famous meanings, is very careful, but also weak in climbing - i.e. excited at first, then suddenly decreases (Khatib, 1994). Ibnu Miskawaih wafat di Isfahan pada 421H/1030M. Some of Ibn Miskawaih's famous works are Tartib As-Sa'adah on morals and politics, Jawidan Khirad, which is a collection of wise expressions, and Tahzib Al-Akhlak about akhlak

According to Ibn Miskawaih, there are four strengths of human character, namely wisdom, simplicity, courage, and justice (Miskawaih, 1994). First; wisdom. Wisdom is the virtue of the soul to think and to know. It lies in knowing all that is, knowing everything divine and human. This knowledge results in understanding which things are possible which should be done, and which should not be done. When the activity of the rational soul is adequate and does not go out of line with itself, and when that soul attains true knowledge, not supposed knowledge but actually ignorance, the soul has attained virtue of knowledge or wisdom. As opposed to this character is ignorance. Second, simplicity. Simplicity is the virtue of the sensual part. This virtue appears in man when he directs his passions according to his (good) judgments. He follows his accurate knowledge, so that he is not carried away by his lusts, and then he is free from and does not become a slave to his passions. As opposed to this power is greedy. Third; courage. Courage is the virtue of the soul of anger, and appears in a person when this soul submits and obeys the soul to think and use good judgment in dealing with things that are harmful. The opposite of this inanity is cowardice.

Fourth; justice. Justice is a virtue of the soul, which arises from the merging of the three virtues above. When the above three virtues act in harmony with each other and submit in harmony so as not to contradict each other. The fruit of this virtue encourages a person to be fair to himself first, and then to be fair to others, and demand justice from them. The opposite of this virtue of justice is cruelty. Based on the four virtues of character above, Ibn Miskawaih further details the virtues that arise from each of these character strengths (Miskawaih, 1994). First; The power of wisdom, its parts are: (1) cleverness (al-dzaka), which means quickly developing conclusions, and the soul's understanding of these conclusions; 
Remember (al-dzikru), is the persistence of a picture of what the soul has grasped, or the imagination; (3) thinking (al-ta'aqul), is an effort to match the objects studied by the soul with the actual state of those objects; (4) clarity of mind (shafau al-dzihni), is the readiness of the soul to conclude what it wants; (5) discernment and brain power (jaudat al-dzihni), is the soul's ability to reflect on past experiences; and (6) the ability to learn easily (suhulat al-ta'allum), is the strength of the soul and acuity in understanding something, with this ability theoretical problems can be understood.

Second; the strength of simplicity, the parts of which are: (1) shame (al-haya), is an act of restraint for fear of doing indecent things, and caution to avoid reproach and insult; (2) calm (al-da'at), is the ability of a person to control himself when he is hit by lust; (3) patience (alshabr), is self-resilient against the onslaught of lust, so as not to get caught up in the rottenness of worldly pleasures; (4) generous (al-sakha '), is the tendency to be in the middle in the matter of giving. That is, to give the property as needed to those who are entitled to receive it; (5) integrity (al-hurriyah), is a virtue of the soul that makes a person look for wealth in the right way, and refrain from looking for wealth on the wrong path; (6) satisfied (al-qana'ah), is not excessive in eating, drinking, and decorating; (7) loyal (aldamatsah), is the attitude of the soul that is subject to praiseworthy things, and is eager to achieve goodness; (8) self-discipline (alintizham), is a mental condition that makes the soul judge everything correctly and arrange it correctly as well; (9) being optimistic (husn alhuda) or having good hopes (husn al-huda) is a desire to equip the soul with noble morals; (10) tenderness (al-musalamah), is a soft heart that reaches the soul from a character free from restlessness; (11) graceful and authoritative (alwiqar), is the toughness of the soul in facing the turmoil of worldly demands; and (12) wara (wara '), which is self-imprinting in order to always do good, so as to achieve soul perfection. In terms of generosity, Ibn Miskawaih explains in more detail as follows: (1) generous (al-karam), is the tendency to easily invest in wealth on the path associated with great things and many benefits; (2) giving importance to others (al-itsar), is a virtue of the soul, with this virtue people refrain from what they want, in order to give it to others who, according to him, are more entitled; (3) willing (al-nail), is rejoicing in doing good and liking it; (4) filial (al-muwasah), is helping friends or people who are entitled to help, and giving them money and food; (5) open arms (al-samahah), is to spend part of what should not be spent; and (7) Forgiveness, namely canceling the part of what should be.

Third; Strength of Courage, including: (1) strength (al-najdah), is self-confidence in facing scary things, so that the owner of this attitude is no longer troubled by anxiety; (2) tenacity ('azam al-himmah), is a virtue of the soul, which makes people happy as a result of being serious; (3) Calmness, which is a virtue of the soul in the face of good luck and bad luck, despite the difficulties that accompany death; (4) Steadfast, is a virtue of the soul that makes a person achieve peace of mind. Not easily possessed by thoughts which prompted him to commit evil, and neither easy nor quick to anger; (5) Being self-controlled, seen at times of conflict, or at times of war. This self-control occurs when the soul is able to control its movements in the above conditions because of the seriousness of them; (6) Mighty, is the willingness to do big jobs, in the hope of getting a good reputation; and (7) tenacity in work (intimal al-kaddi), is the power of the soul that uses the organs of the body for good through good practices and habits.

Fourth; The power of Adil, the parts of which are: (1) friendliness (al-shadaqah), is sincere love, which causes people to pay attention to the problems of their friends and do good for them; (2) social spirit (al-ulfah), is trying to be uniform in opinion and belief. The spirit of mutual cooperation and mutual assistance in managing life is contained in this social spirit (Muarifah, 2018); (3) Silaturrahmi, is sharing the goodness of the world with close relatives; (4) giving reward (mukafa'ah), is repaying kindness in accordance with the kindness received, or even more; (5) good in working together (husn al-syarikah), in taking and giving (take and give), in doing business fairly and in accordance with the interests of the parties concerned; (6) carefulness in deciding issues (husn al-qadha), is appropriate and fair in deciding problems, without being accompanied by feelings of regret and churning; (7) love (tawaddu), is expecting love from those who are considered to have felt satisfied with the way of life they have achieved (meaning zahids), also from those who are considered noble people, by making cute faces and doing actions that are contain their sympathy; (8) Worship, namely nodding the names of Allah Ta'ala, praising him, obeying and submitting to Him, and respecting His defenders, His angels, His prophets, and the priests. Worship here is also following the shari'ah commandments; and (9) 


\section{0| PSIKOPEDAGOGIA}

JURNAL BIMBINGAN DAN KONSELING

Vol.9, No.1, June 2020

piety to Allah, is the peak and perfection of the factors above.

Ibn Miskawaih also explained that virtue is the middle point between the two ends, and in this case these ends are vices and humiliations. (Hamim, 2014). When virtue shifts just a little from its position, then to a lower position, then that virtue approaches one of the disgraces, and diminishes in value according to its proximity from the humiliation it tends to have. It is very difficult to reach this midpoint, and maintaining it when it has been achieved is even more difficult. The midpoint is as in table 1 below (Miskawaih, 1994):

Table 1

Middle Point of Virtue According to Ibnu Miskawaih

\begin{tabular}{|c|c|c|}
\hline $\begin{array}{c}\text { Endpoint of } \\
\text { meanness } 1 \\
\quad(\text { lack ) }\end{array}$ & $\begin{array}{c}\text { Virtue } \\
\text { As a Middle } \\
\text { Point }\end{array}$ & $\begin{array}{c}\text { End of } \\
\text { meanness } 2 \\
\text { ( excessive ) }\end{array}$ \\
\hline $\begin{array}{c}\text { Stupid: } \\
\text { deliberately } \\
\text { informing } \\
\text { thinking fallacy }\end{array}$ & Wisdom & $\begin{array}{l}\text { Stupid: } \\
\text { use the fallacy to } \\
\text { think on } \\
\text { something that is } \\
\text { not good }\end{array}$ \\
\hline $\begin{array}{l}\text { Stupidity : } \\
\text { unable to } \\
\text { grasp } \\
\text { knowledge }\end{array}$ & Smart & $\begin{array}{c}\text { Mental rot: } \\
\text { cunning, guile, } \\
\text { acts of } \\
\text { manipulation }\end{array}$ \\
\hline $\begin{array}{l}\text { Forgot: } \\
\text { neglect of } \\
\text { what that } \\
\text { should be } \\
\text { remembered }\end{array}$ & Remember & $\begin{array}{l}\text { Forgot: } \\
\text { pay attention to } \\
\text { something that is } \\
\text { not to be } \\
\text { remembered }\end{array}$ \\
\hline $\begin{array}{l}\text { Not thinking of } \\
\text { things as they } \\
\text { should }\end{array}$ & $\begin{array}{l}\text { The ability to } \\
\text { think, the } \\
\text { ability } \\
\text { conceptualized } \\
\text { as a right }\end{array}$ & $\begin{array}{l}\text { Too think of } \\
\text { something to go } \\
\text { beyond that } \\
\text { should }\end{array}$ \\
\hline $\begin{array}{l}\text { Sluggish to } \\
\text { grasp the } \\
\text { reality }\end{array}$ & $\begin{array}{l}\text { Quick to } \\
\text { understand }\end{array}$ & $\begin{array}{l}\text { Quickly stamp } \\
\text { something without } \\
\text { understanding it } \\
\text { completely }\end{array}$ \\
\hline $\begin{array}{l}\text { Darkness of } \\
\text { the soul that } \\
\text { causes } \\
\text { sluggishness } \\
\text { to conclude } \\
\text { what is } \\
\text { needed }\end{array}$ & $\begin{array}{c}\text { Clarity of } \\
\text { thought }\end{array}$ & $\begin{array}{l}\text { Berkobarnya soul } \\
\text { so as to prevent } \\
\text { from concluding } \\
\text { what are needed }\end{array}$ \\
\hline $\begin{array}{l}\text { Not thinking } \\
\text { about } \\
\text { something that } \\
\text { should be } \\
\text { thought about }\end{array}$ & $\begin{array}{l}\text { Brilliance and } \\
\text { strength of the } \\
\text { soul }\end{array}$ & $\begin{array}{c}\text { Too thinking } \\
\text { about something } \\
\text { in such a way that } \\
\text { should not be } \\
\text { thought about }\end{array}$ \\
\hline $\begin{array}{l}\text { Find it difficult } \\
\text { or not possible } \\
\text { to understand } \\
\text { something }\end{array}$ & $\begin{array}{l}\text { Learning } \\
\text { ability }\end{array}$ & $\begin{array}{l}\text { It's so easy to } \\
\text { understand } \\
\text { something that it } \\
\text { doesn't stick firmly } \\
\text { in your mind }\end{array}$ \\
\hline $\begin{array}{l}\text { lgnore the } \\
\text { desires of lust } \\
\text { : not seek } \\
\text { pleasure valid } \\
\text { that is needed } \\
\text { by the body so }\end{array}$ & Simple & $\begin{array}{l}\text { Indulging desires } \\
\text { of lust : submerge } \\
\text { themselves in the } \\
\text { enjoyment of } \\
\text { bodily }\end{array}$ \\
\hline
\end{tabular}

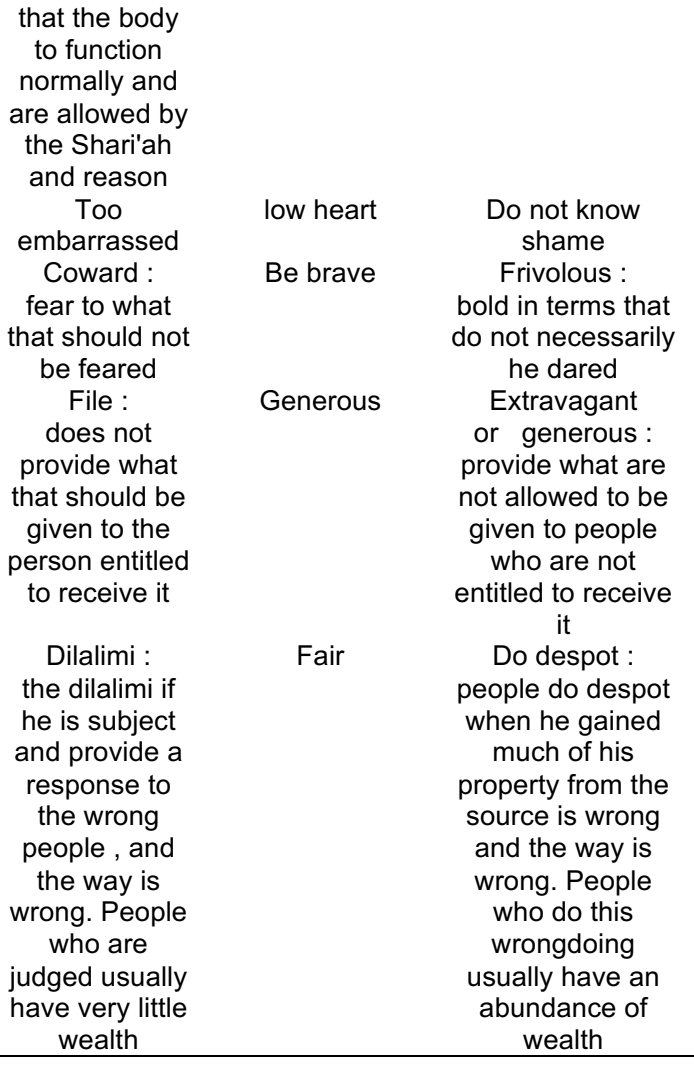

Another middle point that was not mentioned by Ibn Miskawaih is suggested that it be compiled according to the names or terms that exist in each region, using the midpoint method he had described. (Miskawaih, 1994). Imam AlGhazali was born on $450 \mathrm{H} / 1058 \mathrm{M}$ in the city of Gazalah, a small town near Tus in Khurasan, which at that time was one of the centers of knowledge in the Islamic world (Solichin, 2006). His full name is Abu Hamid Muhammad bin Muhammad At-Tusi Al-Ghazali, the names AlGhazali and At-Tusi are attributed to the city of his birth (Azra, $\mathrm{tt}$ ). He was born into a religious family and lived a simple life. His education started from Tus, then to Jurjan, back to Tus, then to Naisabur. In Naisabur, Imam Al-Ghazali studied with Al-Juwaini Imam Al-Haramain until his death, then to several other teachers especially to Abu Ali Al-Farmadhi. In 478H / 1085M Imam Al-Ghazali was received with great honor at the Nizam al-Mulk campus. Sometime before his move to Baghdad in $484 \mathrm{H}$ / 1091 AD, Al-Ghazali experienced a phase of skepticism, and led to the beginning of a passionate search for a more satisfying intellectual attitude and a more useful way of life (Abdullah, 2002).

While at the Nizam al-Mulk campus in Baghdad, Imam Al-Ghazali became one of the most famous people, where he gave lectures 
while passionately pursuing philosophical studies and writing a number of books. However, on 488H / 1095M, he declared his resignation, allegedly because there were so many symptoms of corruption in the campus (Abdullah, 2002), and he chose to live the right way even though it was very simple. Imam AlGhazali then wandered to Damascus, Medina, Makkah, returned to Damascus, then to his homeland Tus. During this time Al-Ghazali lived as a poor Sufi, alone, and spent his time in spiritual training. It was at this time that he wrote a book on the ethics of life which he certainly had lived and taught to his students in a limited manner: the book Ihya 'Ulum Ad-Din. He returned to teaching at the Nizam Al-Mulk campus in Naisabur on 500H / 1106M under pressure from Fakhr Al-Mulk, the son of Nizam Al-Mulk. However, only a few years of teaching, he returned to his hometown, Tus, and established a halaqah for his Sufi students until the end of his life on Jumada Al-Tsaniyah $505 \mathrm{H}$ / December 1111M (Abdullah, 2002).

Imam Al-Ghazali wrote nearly a hundred books, including Ihya 'Ulum Ad-Din on ethics, Al-Mustasyfa min' IIm Al-Ushul on normative ethics regarding good and bad, and Mizan AlA'mal also on ethics (Abdullah, 2002). Meanwhile, according to Imam Al-Ghazali, there are four strengths of human character (Quasem, 1988): First; wisdom or wisdom, is a mental state that allows a person to distinguish right from wrong, between true and false beliefs, and between good and evil deeds, in all actions that are not forced or voluntary (Sidani $\& \mathrm{Al}, 2014)$. Second; courage, is the state of the soul in which the nature of anger is always obedient to reason. The rise and fall of anger obey the commands of reason and shari'ah. Third; patience, is the state of the soul in which the nature of lust is disciplined under the command of reason and syari'ah, so that the nature of restraint ('iffah) is achieved. Fourth; justice, is defined as a state of the soul in which anger and lust are controlled under the orders of reason and shari'ah. Intellect, lust, and anger are kept within their properness and are fulfilled by their respective rights, namely the state of the middle path through which the three things of reason, lust, and anger are applied or balanced.

Based on the four strengths of character above, Imam Al-Ghazali formulated at least twenty-eight virtues which are the details of each of these character strengths. The twentyeight virtues are as follows. First; the power of wisdom, its virtues are as follows: (1) ability to manage; (2) superiority of memory; (3) habit of expressing ideas; (4) correctness of opinion; and (5) mental awareness of hidden evil and subtle actions. Second; courage, including: (1) broad-minded; (2) brave; (3) is male; (4) introspective; (5) fortitude; (6) patience; (7) persistence; (8) suppress anger; (9) know selfesteem; and (10) hospitality and the like. Third; generosity, including: (1) generosity; (2) humility; (3) patience; (4) forgiving; (5) willingness; (6) piety; (7) kindness; (8) helpful; (9) intelligence; and (10) not greedy (greedy). Fourth; justice, including: (1) a balanced and healthy mental state; (2) use body members properly, namely for acts of worship and other purposes; and (3) give rights to everyone and do not harm others in any way (Quasem, 1988).

Table 2

Virtue as Middle Point, According to Imam AlGhazali

\begin{tabular}{|c|c|c|}
\hline $\begin{array}{c}\text { Despicable } \\
\text { Way } 1 \\
\text { (lack ) }\end{array}$ & $\begin{array}{c}\text { Virtue } \\
\text { As a Middle } \\
\text { Point }\end{array}$ & $\begin{array}{c}\text { Despicable } \\
\text { Way } 2 \\
\text { ( excessive ) }\end{array}$ \\
\hline $\begin{array}{c}\text { Ignorance: } \\
\text { Which } \\
\text { includes : } \\
\text { ignorance, } \\
\text { lack of } \\
\text { experience } \\
\text { taking care of } \\
\text { things, } \\
\text { memory } \\
\text { ailments } \\
\text { A Moron, the } \\
\text { pursuit of } \\
\text { objectives } \\
\text { which is true } \\
\text { in a way that } \\
\text { is wrong, but } \\
\text { the purpose } \\
\text { and method } \\
\text { of a g a } \\
\text { moron , } \\
\text { pursuing } \\
\text { objectives } \\
\text { that right by } \\
\text { way wrong, } \\
\text { wrong both }\end{array}$ & $\begin{array}{l}\text { Wisdom: } \\
\text { Which } \\
\text { includes : the } \\
\text { ability to } \\
\text { manage } \\
\text { superiority of } \\
\text { memory } \\
\text { the habit of } \\
\text { expressing } \\
\text { ideas of truth } \\
\text { of opinion } \\
\text { awareness of } \\
\text { the soul will } \\
\text { be works fine } \\
\text { and crime are } \\
\text { hidden }\end{array}$ & $\begin{array}{c}\text { Crime: } \\
\text { Which includes } \\
\text { : cunning, } \\
\text { trickery power } \\
\text { fraud, and } \\
\text { ingenious full- } \\
\text { deception }\end{array}$ \\
\hline $\begin{array}{c}\text { Coward: } \\
\text { Which } \\
\text { include : Low } \\
\text { self, } \\
\text { shortage } \\
\text { price of self, } \\
\text { impatience, } \\
\text { contempt, } \\
\text { narrow view, } \\
\text { reluctant to } \\
\text { accept the } \\
\text { right of }\end{array}$ & $\begin{array}{c}\text { Courage: } \\
\text { Which } \\
\text { includes : } \\
\text { broad } \\
\text { understanding } \\
\text { gallant brave, } \\
\text { be manly, } \\
\text { introspective } \\
\text { self, fortitude } \\
\text {, patience, } \\
\text { constancy } \\
\text { liver , } \\
\text { suppress } \\
\text { angry, know } \\
\text { the price of } \\
\text { self, } \\
\text { hospitality } \\
\text { and the like }\end{array}$ & $\begin{array}{c}\text { Lust rushed: } \\
\text { Which includes } \\
\text { : Like } \\
\text { accentuate } \\
\text { themselves, } \\
\text { arrogance, } \\
\text { angry big , } \\
\text { arrogant and } \\
\text { supercilious }\end{array}$ \\
\hline
\end{tabular}




\section{2 | PSIKOPEDAGOGIA}

JURNAL BIMBINGAN DAN KONSELING

Vol.9, No.1, June 2020

\begin{tabular}{|c|c|c|}
\hline $\begin{array}{l}\text { Extermination } \\
\text { of Lust : } \\
\text { Which } \\
\text { include : less } \\
\text { polite, } \\
\text { stinginess, } \\
\text { preoccupied } \\
\text { with practices } \\
\text { that are not } \\
\text { beneficial, } \\
\text { envy, insults } \\
\text { himself alone } \\
\text { against the } \\
\text { rich, }\end{array}$ & $\begin{array}{c}\text { Availability : } \\
\text { That includes } \\
\text { generosity } \\
\text { humility heart } \\
\text {, patience, } \\
\text { forgiveness , } \\
\text { willingness, } \\
\text { piety, } \\
\text { kindness of } \\
\text { heart, love } \\
\text { help } \\
\text { the } \\
\text { intelligence of } \\
\text { the mind, not } \\
\text { greedy ( } \\
\text { greedy ), the } \\
\text { state of the } \\
\text { soul that is } \\
\text { balanced and } \\
\text { healthy, } \\
\text { using a } \\
\text { member of } \\
\text { the body is } \\
\text { worth that to a } \\
\text { charity of } \\
\text { worship } \\
\text { and intent - } \\
\text { maksud other } \\
\text { giving the } \\
\text { right of every } \\
\text { person and } \\
\text { not harm } \\
\text { others by way } \\
\text { of any }\end{array}$ & $\begin{array}{c}\text { Greedy: } \\
\text { Greed, greed, } \\
\text { do not know } \\
\text { shame, } \\
\text { wasteful, riya ', } \\
\text { tend to slander } \\
\text { the character of } \\
\text { others, taking } \\
\text { the face, } \\
\text { happy if } \\
\text { someone else } \\
\text { distress, insult } \\
\text { the poor }\end{array}$ \\
\hline & $\begin{array}{l}\text { Justice } \\
\text { Injustice }\end{array}$ & \\
\hline
\end{tabular}

In terms of justice, as we can see in table 2 above, Imam Al-Ghazali did not call it the middle way between two despicable roads, because according to him in terms of justice there are only two paths: the road of justice or the way of injustice, justice itself or unfair ( Lubis, 2012). Nothing: fair, unfair, or too fair. This is somewhat different from Ibn Miskawaih's concept above, he states that fair is the middle point between doing wrong, namely arbitrarily not doing justice, and being condemned, namely being treated unfairly. The character strength and virtue in the psychology of Islamic education which was formed from the beginning in the Prophet Muhammad and his companions cannot be separated from the influence of the "virtues" of the pre-Islamic Arab society. The geographic conditions where they live are barren, live in groups and move around, as well as the threat of robbery and war between tribes, build the character of a brave, honest, loyal, and generous spirit. Although initially these characters were for self-esteem, respect and praise, as are the traits of polytheists, Islam, with the monotheism and role models of the prophet Muhammad SWT, succeeded in fostering and directing him into a strength of character that is in line with Islamic teachings (Mawardi, 2015). So that the religion of Islam is held firmly, defended with all its assets and even souls, fought for and spread to all corners of the country and even to the ends of the world, so that it remains firmly up to our time.

In terms of the number and composition of the strength of character and values of virtue developed by positive psychology and the psychology of Islamic education, which in this case is represented by the thoughts of Ibn Miskawaih and Imam Al-Ghazali, are not significantly different. Positive psychology with the power of wisdom and knowledge, courage, humanity and love, justice, temperance, and transcendence, while Ibn Miskawaih with wisdom, simplicity, courage, and justice, and Imam Al-Ghazali with wisdom / wisdom, courage, generosity, and justice, they all seem not so different. It's just that the power of transcendence or sometimes also called spirituality, namely the power of emotions that reaches outside of oneself to connect oneself to something bigger and more permanent: other people, the future, evolution, divinity, or the universe, is not specifically mentioned in the strength of the character of Ibn Miskawaih and Imam Al-Ghazali. Of course we can understand this easily because the four strengths of character formulated by Ibn Miskawaih and Imam Al-Ghazali always state that all characters must be based on reason and shari'ah (Bakri, 2018). and Islamic shari'ah, must accompany and become a barometer of the four strengths of these characters. And this is of course different from positive psychology which nota bene originates from Western civilization, which always tries - either openly or shyly - to separate science and religion (transcendence).

There is something quite different between the strength of the character of positive psychology and the psychology of Islamic education, namely the existence of a middle point or a middle ground in the thoughts of Ibn Miskawaih and Imam Al-Ghazali. Since this is what the shari'ah commands, the aim is to reach a middle ground on all the qualities and qualities of virtue, if it deviates towards one of the two extremes then it should be corrected. The existence of this middle point can make a valuable contribution if we are to compile a measurement for a strength of character or virtue. Usually in positive psychology, the measurement from negative to positive points, while in Islamic educational psychology it offers a measurement of the points of weakness, middle, and strength. The midpoint is the best 
point. In this context it is called the harmony of the educational attainment process (Chong, 2019; Reviews \& Nugroho, 2019; Richards, 2017).

The characters and virtues formulated by Ibn Miskawaih and Imam Al-Ghazali are the result of their own journey and search, and they have carried out in each of them the virtues they formulated (Suryadarma \& Haq, 2015), of course this is with the guidance and guidance given by Allah SWT. This self-seeking process is not easy and short, so when they find it and carry it out seriously, the strengths of character and virtue are formulated (Maghfiroh, 2016). Although we must also admit that Ibn Miskawaih was inseparable from Aristotle's Nichomachean Ethic, which he referred to a lot. It seems that this is somewhat different from the formulation of positive psychology, which traces the strengths and virtues of humans from philosophy, moral teachings, teachings of religions that are practiced by Seligman his associates. Therefore how wonderful it is when studying the strength of character and virtue, we also begin to improve, train and get used to doing these virtues. The psychology of Islamic education is not only theorized but to be applied in everyday life (Fatma, 2020; Prayitno, Ngalim, Sutopo, Rohmadi, \& Yuniawan, 2018; Vauclair, Wilson, \& Fischer, 2014).

\section{CONCLUSION}

Positive psychology with its character strength and virtue provides a new direction for psychology that not only cures mental illness, but also develops positive and high potential each individual possess, and directs one's life to be more meaningful and happy. This is in line with the Islamic pscyhology education, which in Islam, even though it considers that every human being has the potential for evil (fujur) and also good potential (taqwa). However, this potential of taqwa should be encouraged, trained, accustomed to, so that it continues to grow and develop, and become a permanent character.

Character strength and virtue formulated in positive psychology tend to be in accordance with Islamic teachings, thus providing a scientific basis and empirical findings for Muslim psychologists and Islamic educational psychology activists to continue to explore and conduct research in this field of Islamic educational psychology. This established method of positive psychology can be borrowed for study and research in the psychology of Islamic education. The implication is that the psychology of Islamic education can be used as one of the right counseling services for children and students both in the context of informal education at home, non-formal in society, and formal education in schools / madrasas in the current era of global communication.

\section{REFERENCES}

Abdullah, M. A. (2002). Fllsafat etika islam; antara al-ghazali dan kant. Bandung: Mizan.

Azra, A. (2005). Ensiklopedi islam. Jakarta: Ichtiar Baru Van Hoeve.

Bahasa, B. P. (2008). Kamus besar bahasa indonesia. Jakarta: Balai Pustaka.

Bakri, S. (2018). Pemikiran filsafat manusia ibnu miskawaih: telaah kritis atas kitab tahdzib alakhlaq. Jurnal Pemikiran Islam Dan Filsafat, XV(1).

Biyanto, B. (2017). The typology of muhammadiyah sufism: tracing its figures' thoughts and exemplary lives. Indonesian Journal of Islam and Muslim Societies, $\quad 7(2), \quad 221$. https://doi.org/10.18326/ijims.v7i2.221249

Chong, S. W. (2019). College students' perception of e-feedback: a grounded theory perspective. Assessment \& Evaluation in Higher Education, 0(0), 116.

https://doi.org/10.1080/02602938.2019. 1572067

Daniati, S. P., Subiyantoro, S., \& Sutarmi Fadhilah, S. (2019). Natural school culture as a free and fun alternative education in building the students' character. Elementery Education Online, 331-342 18(1), 331-342. https://doi.org/10.17051/ilkonline.2019.5 27617

Fatma, et all. (2020). Directive speech acts in academic discourse: ethnography of communication from gender perspective in higher education. Indonesian Journal on Learning and Advanced Education IJOLAE, 2(1), 27-46. https://doi.org/10.23917/ijolae.v2i1.8829

Hamim, N. (2014). Pendidikan akhlak: komparasi konsep pendidikan ibnu miskawaih dan al-ghazali. Jurnal Studi Keislaman, 18(Juni). 


\section{4 | PSIKOPEDAGOGIA}

JURNAL BIMBINGAN DAN KONSELING

Vol.9, No.1, June 2020

Haque, A. (2004). Psychology from islamic perspective: contributions of early muslim scholars and challenges to contemporary muslim psychologists. Journal of Religion and Health, 43(4), 357-377.

Hart, M. (1989). Martin e.p. seligman. Jakarta: Pustaka .

Hart, M. (1989). Seratus tokoh yang paling berpengaruh. Jakarta: Pustaka Jaya.

Heriyanto, \& Anjaryati, F. (2016). Character building: telaah pemikiran ibnu miskawaih tentang pendidikan karakter. JPII, 111-118.

Hitti, P. K. (2008). Dunia arab. Bandung: Vorking-Van Hoeve.

Izutsu, T. (1993). Etika beragama dalam alquran. Jakarta: Pustaka Firdaus.

Khatib, I. (1994). Kata Pengantar. In I. Miskawaih, Menuju Kesempurnaan Akhlak; Buku Daras Pertama tentang Filsafat Etika (p. x). Bandung: Mizan

Lubis, A. S. (2012). Konsep akhlak dalam pemikiran al-ghazali. Hikmah, 59-66.

Linley, P. A., Joseph, S., Harrington, S., \& Wood, A. M. (2007). The Journal of Positive Psychology: Dedicated to furthering research and promoting good practice positive psychology: past , present, and ( possible ) future positive psychology: past, present, and ( possible ) future. The Journal of Positive Psychology, 1(1)(April 2013), 37-41. https://doi.org/10.1080/1743976050037 2796

Maghfiroh, M. (2016). Pendidikan akhlak menurut kita tahdzib al-akhlak karya ibnu miskawaih. Tadris, 206-218.

Miskawaih, I. (1994). Menuju kesempurnaan akhlak: buku daras pertama tentang etika filsafat. Bandung: Mizan.

Muarifah, A. and Muya Barida. (2018). Model of coping strategy, social interaction, and self adjustment. Jurnal Psikopedagogia, $8(2), 56-66$.

Muhadjir, N. (2011). Psikologi pengembangan karakter; teori, desain penelitian, dan analisis dalam data. Yogyakarta: Rake Sarasin.
Neufeldt, V. (1996). Webster's world college dictionary. New York: Mamillan General Reference.

Okech, D. O. (2016). Implications of life skills education on character development in chil- dren: a case of hill school. Baraton Interdisciplinary Research Journal, 6(5), 73-82.

Park, N., Peterson, C., \& Al, P. E. T. (2004). Strengths of character and well - being. Journal of Social and Clinical Psychology, 23(5), 603-619.

Prasetiya, B. (2018). Dialektika pendidikan akhlak dalam pandangan ibnu miskawih dan al-ghazali. Intiqad: Jurnal Agama Dan Pendidikan Islam, 9950 (December), 249-267.

Prayitno, H.J., et all. (2019). Politicopragmatic p ower of positive hospitality comment of the followers account of indonesia's president jokowi instagram oriented to the character education in the disruption era 52 indonesian journal on learning and advanced education. Indonesian Journal on Learning and Advanced Education IJOLAE, 1(2), 52-71. https://doi.org/10.23917/ijolae.v1i2.8785

Prayitno, H. J., Ngalim, A., Sutopo, A., Pangestu, D. W., Jamaluddin, N., \& Ali, A. H. (2019). Directive politeness act strategy in the discourse of education column in national newspaper as the formation of students' character in indonesia. Humanities \& Social Sciences Reviews, $\quad 7(2), \quad 349-362$. https://doi.org/10.18510/hssr.2019.7241

Prayitno, H. J., Ngalim, A., Sutopo, A., Rohmadi, M., \& Yuniawan, T. (2018). Power, orientation, and strategy of positive politeness used by children at the age of elementary school with javanese cultural background. Humanus: Jurnal IImiah IImu-IImu Humaniora, 17(2), 164-173. https://doi.org/10.24036/humanus.v17i2. 101371

Qurrota A'yun, M. Fatwa Tentama, Nina Zulida Situmorang. 2017. The image of subjective well being on santriwati 
pondok pesantren. Jurnal Psikopedagogia, 7(1), 1-8.

Rahmat, J. (2005). From Suffering to Savoring. In M. E. Seligman, Menciptakan kebahagiaan dengan psikologi positif: Authentic Happinesa (pp. 1-10). Bandung: Mizan.

Reviews, S. S., \& Nugroho, A. (2019). A future teacher trend: a sociological study on freedom. Humanities \& Social Sciences Reviews, 7(3), 306-314.

Richards, J. C. (2017). Teaching english through english: proficiency, pedagogy and performance. RELC Journal, 48(1), 7-30.

https://doi.org/10.1177/0033688217690 059

Seligman, M. E. (2005). Authentic happines: menciptakan kebahagiaan dengan psikologi positif. Bandung: Mizan.

Setiawan, A. (2014). Abstract: Dinamika Islam, 14(1), 1-12.

Sidani, Y., \& Al, A. (2014). New conceptual foundations for islamic business ethics: the contributions of abu-hamid alghazali. J Bus Ethics. https://doi.org/10.1007/s10551-0142136-5

Solichin, M. M. (2006). Belajar dan mengajar dalam pandangan al-ghazali. Tadris, 138-153

Suryadarma, Y., \& Haq, A. H. (2015). Pendidikan akhlak menurut imam alghazali. At-Ta'dib, 361-381.

Susilo, S., \& Dalimunthe, R. (2019). Moderate southeast asian islamic education as a parent culture in deradicalization: urgencies, strategies, and challenges. Religions, $\quad 10(1), \quad 45$. https://doi.org/10.3390/rel10010045

Syarif, M. (1996). Para filosof muslim. Bandung: Mizan.

Taufiqharahap, M. (2017). IJLRES International Journal on Language , Research and Education Studies ISSN : 2580-6777 ( p ); 2580-6785 ( e ). International Journal on Language, Research and Education Studies, 1(1), 119-129.
Vauclair, C. M., Wilson, M., \& Fischer, R. (2014). Cultural conceptions of morality: Examining laypeople's associations of moral character. Journal of Moral Education, 43(1), 54-74. https://doi.org/10.1080/03057240.2013. 873365. 